\title{
Future Perspectives for Biosafety in Brazil
}

\author{
Luiz Antonio Barreto de Castro* \\ Castro LAB, Fundação Getúlio Vargas, Brazil
}

Submission: September 05, 2017; Published: September 25, 2017

*Corresponding author: Luiz Antonio Barreto de Castro, Fundação Getúlio Vargas, Brazil, Email: luizantoniobarretodecastro@gmail.com

\section{Introduction}

The Biosafety legislations were paramount for the development of Biotechnology in Brazil. I became familiarized with the theme as a consultant for the World Bank that demanded that Brazil had available guidelines in this area to celebrate a contract with Brazil in the area of Science and Technology. I elaborated the Biosafety Guidelines for the PADCT/ Biotechnology that became effective in 1986, very much using subsidies that were available in the Guidelines produced by the NIH after the Asilomar Conference during the seventies. We had no Biosafety Lawin Brazil until the Law 8974 [1] was enacted in January of 1995.The law called for the establishment of CTN Bio-Technical National Commission of Biosafety. As National Secretary for Research and Development at the Ministry of Science and Technology I established the first CTN Bioteam and was President of the Commission from 1996 till 1999. During this period Brazil approved in 1998 the first genetically modified plant, the soybean RR presented by the Monsanto Company. After this approval Brazil experienced the most aggressive campaign against GMOS that brought together NGOs like the Greenpeace to team with the Judiciary. That culminated with a decision to ban GMOs by a Judge called Prudent that sentenced that: GMOs utilize alien genes that will give rise to populations that will compromise the future generations in the Planet. Until 2005 Brazil could not legally deliver any GM plant but soybean RR entered illegally in the Country from Argentina and were largely cultivated in the border State of Rio Grande do Sul. More than one million hectares were soon cultivated with soybean RR from Argentina. Those that were against GMOs wanted to burn these cultivations. President Lula da Silva prevented this and demanded a review of the legislation .He approved in March of the same year, the law 11.105 [2] that strengthened the power of CTN Bio and created the Ministerial Council of Biosafety as the last resort for the decisions of the CTN Bio. The Council never opposed technically decisions of the Technical Commission but accepted demands of other nature .The decisions of the Council were final. Unquestionably during twenty years of the history of Biosafety in Brazil the Country went thru difficulties particularly until the law 11.105 was enacted. The most aggressive campaign was named: For a Country free of GMOS. During the last twelve years although many still oppose to GMOs no judicial attempts were made. What have we learned during this period and what are the perspectives for the future? This is objective of this Opinion Paper.

\section{The Ordeal of Gmos Worldwide}

After more than fifty years dealing with Biology I have never found a technology that has been more regulated than the so called Recombinant DNA. Since the Asilomar Conference in 1973 many scientist considered that these regulations were needed to avoid any undesirable impacts of the technology to human health and to the environment. In 1973 I was a PhD student at UC Davis and remember clearly that the most concern that the scientists had about the technology in San Diego was related to its use to gene therapy in humans. United States declared a moratorium until NIH regulations that followed and were adopted by most Countries .NIH rules were responsible for the fact that to date very few (2 in the area of gene therapy) undesirable consequences of the use of recombinant DNA technology occurred. Even though GMOs face an unbelievable opposition in many Countries particularly in Europe. Many examples can be presented to illustrate this opinion. I will mention a couple

Four hundred protesters invaded IRRI in the Philippines and uprooted the genetically modified rice plants growing inside experimentally. This happened in July of 2013. The rice plants were endowed with a gene from corn and another from a bacterium, making it the only variety in existence to produce beta carotene, the source of vitamin A. Its developers Ingo Potrykus and Peter Beyercalled it "Golden Rice." [3]. The destruction of the field trial, and the reasons given for it, touched a nerve among scientists around the world, spurring them to counter assertions of the technology's health and environmental risks. On a petition supporting Golden Rice circulated among scientists and signed by several thousand, many vented a simmering frustration with activist organizations like Greenpeace, which they saw as playing on misplaced fears of genetic engineering in both the developing and the developed worlds. Lack of Vitamin A causes blindness in 
a quarter-million to a half-million children each year. It affects millions of people in Asia and Africa and so weakens the immune system that some two million die each year of diseases they would otherwise survive. In this case, many more millions will needlessly suffer blindness and death because Golden Rice is still not available to them. No group, regardless of its intentions, has the right to condemn a technology without evidence. It is an unconscionable criminal act to destroy a field trial conducted in accordance to international safety norms, stated a petition put together by Neidenbach [4].

In 1992 Acquabounty approached the Food and Drug Administration about selling a genetically modified salmon that grew faster than normal fish. In 1995, Aqua Bounty formally applied for approval. More than 17 years later, the public comment period, one of the last steps in the approval process, was finally supposed to conclude. The Aqu Advantage salmon is an Atlantic salmon that carries two foreign genes: a growth hormone gene from the Chinook salmon that is under the control of a genetic "switch" from the ocean pout, an eel-like fish that lives in the chilly deep and feeds normally during the winter. Atlantic salmon produce growth hormone only in the warm summer months, but these genetic adjustments let the fish churn it out year round. As a result, the Aqu Advantage salmon typically reach their adult size in a year and a half, rather than three years. Sources within the government of Barak Obama say that the White House debated the political implications of approving the GM salmon, and move likely to infuriate a portion of its base. Many years ago I published an Article saying that science and politics should never mix. Recently I published this finding in the Bio entrepreneur blog at Nature [5] combing two important examples. Taking from the blog I said that GM salmon in the FDA constitutes the longest case in history of a GM organism attempting to be cleared anywhere in the world. The United States has a role as leader in the subject of commercializing Gm plants as food. I wrote a letter to President Obama. Others have, as well. In mine, I essentially said that science and politics do not mix. In the last century Stalin following Lisenko a young geneticist denied the Russian people the right to study in the schools the modern genetics of Thomas Hunt Morgan. Morgan won the Nobel Prize in Physiology in 1933 and established a Division of Biology at Caltech that yielded seven other Nobel Prizes. Russia today imports grains, a lot of it from Brazil, where the genetics of Morgan was fortunately widely disseminated amongst our geneticists. Finally in August 4th twenty five years later Acqu abounty announced that the first GM salmon was sold in Canada [6]. This is the first animal genetically modified to be used as food. It is clear that since 1973 when Herbert Boyer first expressed the insulin gene in E coli and despite of the fact that the responsible and safe use of this technology over more than fourty four years resulted in few impacts caused by gene therapy as the only negative effects of what now we call GMOs, the technology is not popular as in fact science in general is not popular [7]. There is a myth that transgenic organisms are bad for you, even after many decades lacking scientific evidence to support this. At CENARGEN/EMBRAPA (Carlos Bloch personal communication) peptides could be genetically inserted into cocoa to prevent "witches' broom", a devastating crop disease. The cocoa industry did not accept this solution because the peptide was derived from the genome of a frog. We have a long-standing partnership with Elizabeth Maga at UCDavis to introduce by genetic engineering insulin and lacto ferrin into dairy milk to reduce infant diarrhea that claims the lives of millions particularly in Africa but also thousands in the Northeast of Brazil. The dairy industry, at least in Brazil (I cannot speak about Europe, where it may be worse), will never accept it because they believe that people will not consume a genetically engineered milk. One company in Brazil told me to produce insulin by my method and purify it, and said the company would then add it to the milk but would not say the method used was genetic engineering. This persists for many decades despite of a lack of scientific evidence as mentioned before. I think this will not change, and what is worse is that industry and some regulatory agencies will not accept GMOs. The Golden Rice has never reached the market, while millions die due to the lack of Vitamin A. Even the GM sterile mosquito produced by Oxitec is waiting for approval at FDA that only recently cleared a genetically modified animal. Fortunately the same mosquito was released by CTNBIO in Brazil where the dengue fever affects hundreds of thousands of people. It was not however released by ANVISA (equivalent to FDA) so far.

\section{Gmos in Brazil and the Perspectives for the Future}

Brazil is second to the United States in the cultivation of genetically modified plants. In 2016 Brazil retained this position with 49.1 million hectares of biotech crops planted, representing $27 \%$ of the global world cultivation of 185.1 million hectares [8] Brazil's total biotech crop of 49.14 million hectares is an increase of $11 \%$, from 2015 . This 4.9 million hectare increase was by far the highest increase in any country worldwide in 2016 making Brazil the engine of growth in biotech crops worldwide. Biotech crops planted include: 32.7 million hectares of biotech soybean; 15.7 million hectares of biotech maize (summer and winter maize); and 0.8 million hectares of biotech cotton. The total planted area of these three crops in Brazil was estimated at 52.6 million hectares of which 49.14 million hectares or 93.4\% was biotech. From 2003 to 2016, Brazil has approved 57 events for food, feed processing and cultivation including 33 maize events, 12 cotton events, 10 soybean events, one bean event and one eucalyptus. In 2017 the first genetically modified sugarcane resistant to herbicide was approved by CTN Bio. Brazilian, multinational seed companies and the public sector research institutions are working on the development of various biotech crops. Currently, there are a number of biotech crops in the pipeline waiting for commercial approval, of which the most important are beans, sugarcane, potatoes, papaya, rice and citrus. Except for beans and sugarcane, most of these crops are in the early stages of development and approvals are not expected within the next five years. 
My opinion is that we could have approved more than 57 events at CTN Bio if the costs one has to pay to release an event for commercial use were not so high. These costs are easily affordable by multinational companies but not for the majority of the public institutions. Amongst the 57 events released by CTN Bio only bean resistant to the Golden Mosaic was produced by EMBRAPA the largest public company working in science and technology for agriculture. Not one University in Brazil could pay for these costs. I am not criticizing the presence of multinationals seed companies in Brazil. Since 1960 Brazil doubled its grain production that was 30 million tons in 1960 . We expect to produce 240 million tons of grain in 2020. These results are due largely to the presence of EMBRAPA that was created in 1973 and the adoption of Brazil for investments by the multinationals after we passed a law deciding to produce seed by private and not by public institutions in 1965. However even admitting that I was largely responsible for these regulations early in the eighties we have to simplify the process to release events at CTN Bio because the history demonstrated that the technology is safe and no impacts to human health and to the environment occurred. Biology is complex and we were careful to do no mistakes the history of the biosafety in Brazil is getting close to $1 / 4$ of a century. We have to review the law and reduce costs to stimulate public companies to come aboard. One example is comparability studies that are expensive; Biology like I said is complex and extremely rich in new discoveries that may turn recombinant DNA a technology of the past .I am specifically calling attention to the gene editing and CRISPRC as 9 new technology that is being used largely to answer the majority of the questions in Biology. So far they have not faced regulatory hurdles because they are not transgenics. The regulatory agencies will now work to determine if rules are needed. Certainly this will be the case if human embryos are intended to be targeted with gene editing, but possibly not for plants and other animals. The decision is not out yet. This may end up being the democratization of genetic engineering because the technology is in the hands of everybody. I discussed this issue in the Blog Bio entrepreneur published by Nature [9] unfortunately considering how agencies behave I am not optimistic. Biology is so rich that gene editing may not be the end of recombinant DNA because now we can express metabolic pathways [10] for biodiversity rich countries like Brazil this may be the technology of the future.

\section{References}

1. (1995) Law № 8.974 .

2. (2005) Law № 11.105 .

3. Harmon Amy (2013) Golden Rice: Lifesaver? New York Times-Sunday Review, USA.

4. Asis Marlo (2015) Golden rice as a way to prevent blindness in children gains public support. Cornell Alliance for Science, USA.

5. Luiz Antonio Barreto de Castro (2015) Mixing Science and Politics, Brazil.

6. Waltz E (2017) First Genetically Engineered Salmon Sold in Canada. Nature international weekly journal of sciences.

7. Luiz Antonio, Barreto DC (2017) The Ordeal of Richard Feverel: Science Versus Nature 2(1): 47-66.

8. Isaa Briefs (2016) Global Status of Commercialized Biotech /GM Crops, International Service for the Acquisition of Agri-biotech Applications , Brazil, pp. 1-125.

9. Luiz Antonio Barreto de Castro (2015) Transgenesis vs. gene editing. Bioentrepreneur 18: 25.

10. Law W, Sattely ES (2015) Six enzymes from mayapple that complete the bioisymthetic pathway to the etoposide aglycone Science 349(3253): $1224-1228$

\section{Your next submission with Juniper Publishers} will reach you the below assets

- Quality Editorial service

- Swift Peer Review

- Reprints availability

- E-prints Service

- Manuscript Podcast for convenient understanding

- Global attainment for your research

- Manuscript accessibility in different formats

( Pdf, E-pub, Full Text, Audio)

- Unceasing customer service

Track the below URL for one-step submission https://juniperpublishers.com/online-submission.php 